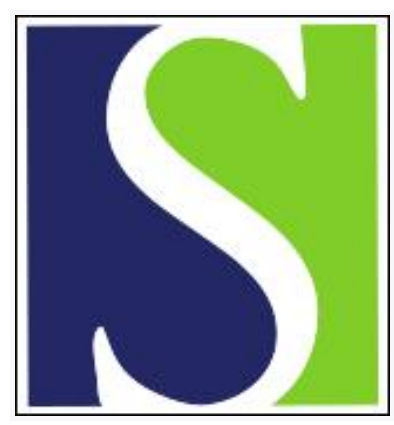

Scand J Work Environ Health 2003;29(2):94-99

https://doi.org/10.5271/sjweh.710

Issue date: Apr 2003

Pregnancy outcome among offspring of airline pilots and cabin attendants

by Irgens $\AA$, Irgens LM, Reitan JB, Haldorsen T, Tveten U

Affiliation: Department of Occupational Medicine, Haukeland Hospital, N-5021 Bergen, Norway. aagot.irgens@helse-bergen.no

Refers to the following text of the Journal: 2000;26(2):106-111

Key terms: airline pilot; aviation; birth defect; birthweight; cabin attendant; cosmic radiation; epidemiology; malformation; offspring; perinatal death; pregnancy outcome; preterm birth

This article in PubMed: www.ncbi.nlm.nih.gov/pubmed/12718494

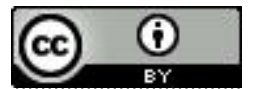




\title{
Pregnancy outcome among offspring of airline pilots and cabin attendants
}

\author{
by Ågot Irgens, MSc, ${ }^{1}$ Lorentz M Irgens, DrMed ${ }^{2,3}$ Jon B Reitan, DrMed, ${ }^{4}$ Tor Haldorsen, MSc, ${ }^{5}$ \\ Ulf Tveten, $M S c^{6}$
}

\author{
Irgens Å, Irgens LM, Reitan JB, Haldorsen T, Tveten U. Pregnancy outcome among offspring of airline pilots and \\ cabin attendants. Scand J Work Environ Health 2003;29(2):94-99.
}

Objectives This study assessed the occurrence of perinatal death, low birthweight, preterm birth, and birth
defects (total, major, neural tube defects, total cleft, cleft palate, hypospadias, and Down syndrome) in the
offspring of airline pilots and cabin attendants.

Methods A cohort of offspring of airline pilots and cabin attendants was established and characterized in terms of parental exposure to cosmic radiation the year before birth or ever. Pregnancy outcome was derived from the Medical Birth Register of Norway. The reference group comprised offspring of parents without occupational exposure to cosmic radiation.

Results No deviant risks were observed for the offspring of male pilots, either for the year preceding birth $(\mathrm{N}=2111)$ or ever $(\mathrm{N}=2356)$. Specific birth outcomes were fewer for the pilots than for the referents $(\mathrm{N}=1621$ 186), except for Down syndrome, which was more frequent [odds ratio (OR) 1.41, 95\% confidence interval $(95 \% \mathrm{CI}) 0.53-3.76]$. For exposure the year preceding birth ( $\mathrm{N}=2512)$, the risk of low birthweight was lower for the female cabin attendants than for the referents (adjusted OR 0.83, 95\% CI 0.69-1.00), while Down syndrome was more frequent ( OR 1.44, 95\% CI 0.60-3.47). For exposure ever $(\mathrm{N}=3346)$, the risk of low birthweight was lower (OR $0.82,95 \%$ CI $0.70-0.96$ ) for the cabin attendants, while hypospadias (OR 1.18, 95\% CI 0.61-3.04) and Down syndrome (OR 1.79, 95\% CI 0.03-3.45) were more frequent.

Conclusions In general, offspring of air pilots and cabin attendants do not seem to be at increased risk of adverse pregnancy outcome.

Key terms aviation, birth defects, birthweight, cosmic radiation, epidemiology, malformations, perinatal death, preterm birth.

The work environment of airline personnel comprises a series of exposures, ranging from the disruption of circadian rhythms by irregular workhours to cosmic radiation (1-2), and for the pilots low electromagnetic fields as well (3). Cosmic radiation, in terms of ionizing radiation, (4) is associated with excess risks of cancer, but not necessarily at doses observed in airplanes. The oncogenicity of electromagnetic fields has also been brought into question (5).
Similar associations with adverse pregnancy outcome have been suspected. Thus Down syndrome has been found to be associated with low doses of ionizing radiation in general (6). Excess risk of Down syndrome among infants of female cabin attendants has been focused on after a previous Norwegian study reported a slightly increased relative risk (7). In this Norwegian study, data on outcome were derived from the Medical Birth Register of Norway, while data on exposure

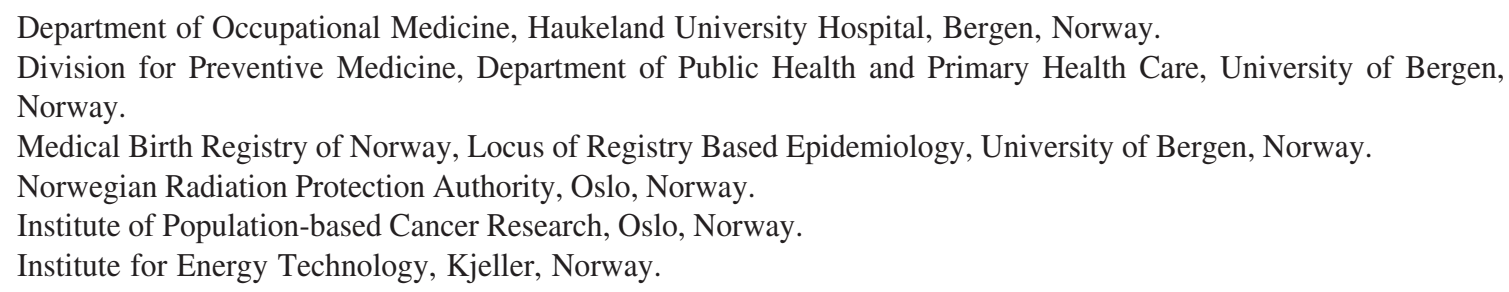

Correspondence to: Ågot Irgens, Department of Occupational Medicine (Yrkesmedisinsk avdeling), Haukeland Hospital, N5021 Bergen, Norway. [E-mail: aagot.irgens@ @else-bergen.no] 
stemmed from a general population census register of occupations, in which job titles are given for the years 1970 and 1980 in crude, nonspecific occupational categories. To an unknown extent, misclassification of exposure that biases relative risks towards unity in terms of occupation must occur in censuses. Thus in a future study there was need for more reliable data on exposure.

A cohort of airline pilots and cabin attendants was established with data obtained from the Norwegian Civil Aviation Administration (CAA), and an additional cohort was established with data from an airline, Scandinavian Airline Systems (SAS). Both cohorts offered a more precise categorization of exposure than in the previous Norwegian study with respect to both persons exposed and quantification of the exposure in terms of time (8-9). The CAA cohort has previously been utilized in a study of cancer incidence (10-11). In our present study, these cohorts were linked with the Medical Birth Register of Norway to assess whether exceeding risks of adverse pregnancy outcome occur for the offspring of airline pilots and cabin attendants.

\section{Subjects and methods}

In Norway, the CAA authorizes commercial pilots and cabin attendants. A cohort was established using data from the files of the Personnel Licensing Section [name, date of birth, company (if available) and dates of license renewals through 1994] for pilots from 1946 and for cabin attendants from 1950. This cohort was divided into four groups comprising male and female pilots, as well as male and female cabin attendants. For all four groups, exposure data for the period 1950-1994 were used in the analyses.

For each pilot, exposure data were obtained from the CAA with annual data on hours in the air. From SAS, annual data were obtained for the complete SAS worldwide route system back to 1960. Several experienced SAS pilots, information provided on flight profiles, spent time at different cruise levels on different flights and also time taxing at different airports. Assumptions based on this information were applied in calculations using the computer program CARI, developed by the United States Federal Aviation Administration, to establish typical dose rates for pilots flying different aircraft and subsequently to calculate the individual annual exposure for each pilot. In these calculations, variations in the cosmic radiation field with altitude, latitude, and time (due to variations in solar activity) were taken into consideration. Details of these calculations have been reported elsewhere $(8,9,12)$.

For the cabin attendant group, exposure data were derived from the CAA, in terms of number of days with license. Details about this system have been reported elsewhere (11). For every year during the observation period, each cabin attendant was characterized by the number of days with a license, used as a proxy variable for occupational exposure.

For SAS cabin attendants, partly overlapping the CAA group, data were available for 1977-1998 on the number of hours in the air, and the dose of cosmic radiation could be calculated, as described for the pilots.

The birth was defined as the unit of analysis. Established in 1967, the Medical Birth Registry of Norway was unable to provide data on all births of the oldest members of the cohort.

After linkage, based on the national identification number, it appeared that altogether 2367 births were parented by airline pilots in 1967-1994, among whom 2356 were male and only 11 were female. Thus the analyses of adverse outcome were restricted to the offspring of male pilots, and the analyses were performed according to the father's exposure the year preceding the birth and ever. The exposure variables were father's hours in the air, as well as the calculated dose of radiation divided into two by the median: (i) hours in the air the year preceding the birth (ie, hours last year) $(\mathrm{N}=2111$ births, median 425 hours), (ii) dose the year preceding the year of birth (ie, dose last year) $(\mathrm{N}=2111$ births, median $51 \mathrm{mSv}$, (iii) hours in the air all years preceding the year of birth (ie, hours ever) ( $\mathrm{N}=2356$ births, median 2917 hours), and (iv) dose all years preceding the year of birth (ie, dose ever) ( $\mathrm{N}=2356$ births, median 204 $\mathrm{mSv}$ ). The "ever" variable comprised years of exposure back to 1950 .

In the cabin attendant group, 3716 births were parented in 1967-1994, 370 of the attendants being male and 3346 being female. Thus the analyses of adverse outcome were restricted to births of female cabin attendants, and the analyses were performed according to the mothers' exposure the year preceding the birth and ever. The exposure variable was whether the mother was licensed to work in the air the year preceding the birth or not, and the cumulative number of days with a license: (i) licensed or not (ie, last year) ( $\mathrm{N}=2512$ births) and (ii) licensed workdays all years before the year of birth (ie, days ever categorized as above or below the median) ( $\mathrm{N}=3346$ births). The "ever" variable comprised years of exposure back to 1950 .

The exposure variables for the SAS group of cabin attendant births in 1977-1998 in terms of hours in the air and dose were specified as for the births of the pilots: (i) hours in the air the year preceding the year of birth (ie, hours last year) ( $\mathrm{N}=991$ births, median 319 hours, (ii) dose the year preceding the year of birth (ie, dose last year) ( $\mathrm{N}=991$ births, median 619 $\mathrm{mSv}$ ), (iii) hours in the air all years preceding the year of birth (ie, hours ever) ( $\mathrm{N}=1093$ births, median 2596 
hours), (iv) dose all years preceding the year of birth (ie, dose ever) ( $\mathrm{N}=1093$ births, median $4843 \mathrm{mSv})$. The "ever" variable comprised years of exposure back to 1977.

Data on outcome, comprising all births after 16 weeks of gestation in the country since 1967, were obtained from the Medical Birth Registry of Norway (13).

The following outcome variables were established: (i) birth defects, total and specified as major (14); neural tube defects, total cleft lip, cleft palate, hypospadias, and Down syndrome; (ii) proportion of low birthweight ( $<2500 \mathrm{~g}$ ) births; (iii) proportion of preterm $(<37$ weeks) births; (iv) perinatal mortality comprising all births after 16 weeks of gestation (including deaths during the first week of life).

The referents were all other births in Norway during the actual observation periods. Infants of airline pilots and flight attendants born prior to parental exposure were not included in either the exposure group or the reference group.

Statistical analyses were performed with the statistical program SPSS 9.0 (15).

Multiple logistic regression analyses provided odds ratios (OR) and $95 \%$ confidence intervals $(95 \% \mathrm{CI})$. The odds ratios were adjusted for year of birth, maternal age, and place of birth. In addition, odds ratios for low birthweight were adjusted for birth order.

\section{Results}

\section{Male pilots}

Perinatal mortality was lower among the offspring of the airline pilots than among the reference group, both when the father was active as an airline pilot the year before the birth (13.7 per 1000 versus 17.9 in the reference) and when he had been active any year before (14.9 per 1000 versus 17.9) (table 1). However, when adjusted for maternal age, as well as year and place of birth, the reduced odds ratios shifted towards unity (table 2).

The proportions of low birthweight (4.6\%) and preterm birth $(5.3 \%)$ for exposure the year preceding birth were lower than in the reference population $(5.1 \%$ and $6.3 \%$, respectively) (table 1 ), but the adjusted odds ratios ( 0.88 and 0.85 , respectively) were slightly less than unity (table 2).

The rates of birth defects, total and major, were below the expected rates (table 1 ). The adjusted odds ratios were close to unity (table 2).

Apart from the Down syndrome, the rates of the specific birth defects were lower than those of the referents; however, due to the lack of statistical power, no conclusions could be drawn (table 2). On the other hand, for exposure the year preceding birth, Down syndrome

Table 1. Perinatal mortality and the occurrence of low birthweight, preterm birth, and selected birth defects among infants of 3701 male airline pilots by the father's hours in the air and the calculated dose of exposure to cosmic radiation the year preceding the births and all years prior to the births and among all other infants (reference) in Norway in 1967-1995.

\begin{tabular}{|c|c|c|c|c|c|c|c|c|c|c|c|c|c|c|c|}
\hline \multirow[t]{2}{*}{ Exposure } & \multirow[t]{2}{*}{$\begin{array}{l}\text { Infants } \\
\text { (N) }\end{array}$} & \multicolumn{2}{|l|}{$\begin{array}{l}\text { Perinatal } \\
\text { mortality }\end{array}$} & \multirow{2}{*}{$\begin{array}{l}\text { Low birth- } \\
\text { weight } \\
(\%<2.5)\end{array}$} & \multirow[t]{2}{*}{$\begin{array}{l}\text { Preterm birth } \\
(\%<37 \text { weeks) }\end{array}$} & \multicolumn{2}{|c|}{ Birth defects } & \multicolumn{2}{|c|}{$\begin{array}{l}\text { Major birth } \\
\text { defects }\end{array}$} & \multicolumn{2}{|l|}{ Total cleft } & \multicolumn{2}{|c|}{ Hypospadias } & \multicolumn{2}{|l|}{$\begin{array}{l}\text { Down } \\
\text { syndrome }\end{array}$} \\
\hline & & Per 1000 & $\mathrm{~N}$ & & & Per 10000 & $\mathrm{~N}$ & Per 1000 & $\mathrm{~N}$ & Per 10000 & $\mathrm{~N}$ & Per 10000 & $\mathrm{~N}$ & Per 10000 & $\mathrm{~N}$ \\
\hline \multicolumn{16}{|l|}{ Year preceding birth } \\
\hline \multicolumn{16}{|l|}{ Hours in air } \\
\hline Above median & 1052 & 7.6 & 8 & 4.2 & 6.1 & 180.6 & 19 & 104.6 & 11 & - & . & - & . & 19.0 & 2 \\
\hline Below median & 1059 & 19.8 & 21 & 5.0 & 5.0 & 330.5 & 35 & 188.9 & 20 & 18.9 & 2 & 9.4 & 1 & 18.9 & 2 \\
\hline Total exposed & 2111 & 13.7 & . & 4.6 & 5.3 & 255.8 & . & 146.8 & . & 9.5 & . & 4.7 & . & 18.9 & . \\
\hline Reference & 1621186 & 17.9 & . & 5.1 & 6.3 & 277.2 & . & 183.5 & . & 14.0 & . & 12.7 & . & 10.3 & . \\
\hline \multicolumn{16}{|l|}{ Dose } \\
\hline Above median & 1140 & 10.5 & 12 & 5.2 & 6.0 & 271.9 & 31 & 131.6 & 15 & 8.8 & 1 & . & . & 8.8 & 1 \\
\hline Below median & 971 & 17.5 & 17 & 3.9 & 5.0 & 236.9 & 23 & 164.8 & 16 & 10.3 & 1 & 10.3 & 1 & 30.9 & 3 \\
\hline Total exposed & 2111 & 13.7 & . & 4.6 & 5.3 & 255.8 & . & 146.8 & . & 9.5 & . & 4.7 & . & 18.9 & . \\
\hline Reference & 1621186 & 17.9 & . & 5.1 & 6.3 & 277.2 & . & 183.5 & . & 14.0 & . & 12.7 & . & 10.3 & . \\
\hline \multicolumn{16}{|l|}{ Ever } \\
\hline \multicolumn{16}{|l|}{ Hours in air } \\
\hline Above median & 1178 & 14.4 & 17 & 5.5 & 7.0 & 220.7 & 26 & 127.3 & 15 & 8.5 & 1 & - & . & 17.0 & 2 \\
\hline Below median & 1178 & 15.3 & 18 & 4.0 & 4.8 & 322.6 & 38 & 178.3 & 21 & 17.0 & 2 & 8.5 & 1 & 17.0 & 2 \\
\hline Total exposed & 2356 & 14.9 & . & 4.8 & 5.6 & 271.6 & . & 152.8 & . & 12.7 & . & 4.2 & . & 17.0 & . \\
\hline Reference & 1621186 & 17.9 & . & 5.1 & 6.3 & 277.2 & . & 183.5 & . & 14.0 & . & 12.7 & . & 10.3 & . \\
\hline \multicolumn{16}{|l|}{ Dose } \\
\hline Above median & 1280 & 14.1 & 18 & 5.3 & 6.5 & 289.1 & 37 & 148.4 & 19 & 15.6 & 2 & . & . & 23.4 & 3 \\
\hline Below median & 1076 & 15.8 & 17 & 4.2 & 5.1 & 250.9 & 27 & 158.0 & 17 & 9.3 & 1 & 9.3 & 1 & 9.3 & 1 \\
\hline Total exposed & 2356 & 14.9 & . & 4.8 & 5.6 & 271.6 & . & 152.8 & . & 12.7 & . & 4.2 & . & 17.0 & . \\
\hline Reference & 1621186 & 17.9 & . & 5.1 & 6.3 & 277.2 & . & 183.5 & . & 14.0 & . & 12.7 & . & 10.3 & . \\
\hline
\end{tabular}


Table 2. Odds ratios $(\mathrm{OR})$ with $95 \%$ confidence intervals $(95 \% \mathrm{Cl})$ for perinatal mortality, low birthweight, preterm birth, and selected birth defects among the infants of 3701 male airline pilots and 3693 female cabin attendants in Norway in 1967-1995.

\begin{tabular}{|c|c|c|c|c|c|c|c|c|c|c|c|c|c|c|c|c|c|c|c|c|}
\hline \multirow[t]{2}{*}{ Exposure } & \multicolumn{2}{|c|}{$\begin{array}{l}\text { Perinatal } \\
\text { mortality }\end{array}$} & \multicolumn{2}{|c|}{$\begin{array}{l}\text { Low birth- } \\
\text { weight }\end{array}$} & \multicolumn{2}{|c|}{$\begin{array}{l}\text { Preterm } \\
\text { birth }\end{array}$} & \multicolumn{2}{|c|}{$\begin{array}{l}\text { Birth } \\
\text { defects }\end{array}$} & \multicolumn{2}{|c|}{$\begin{array}{l}\text { Major birth } \\
\text { defects }\end{array}$} & \multicolumn{2}{|c|}{ Neural tube } & \multicolumn{2}{|c|}{ Total cleft } & \multicolumn{2}{|c|}{ Cleft palate } & \multicolumn{2}{|c|}{ Hypospadias } & \multicolumn{2}{|c|}{$\begin{array}{l}\text { Down } \\
\text { syndrome }\end{array}$} \\
\hline & $\mathrm{OR}^{\mathrm{a}}$ & $95 \% \mathrm{Cl}$ & $\mathrm{OR}^{\mathrm{b}}$ & $95 \% \mathrm{Cl}$ & $\mathrm{OR}^{\mathrm{a}}$ & $95 \% \mathrm{Cl}$ & $O R^{a}$ & $95 \% \mathrm{Cl}$ & $\mathrm{OR}^{\mathrm{a}}$ & $95 \% \mathrm{Cl}$ & $\mathrm{OR}^{\mathrm{a}}$ & $95 \% \mathrm{Cl}$ & $\mathrm{OR}^{\mathrm{a}}$ & $95 \% \mathrm{Cl}$ & $\mathrm{OR}^{\mathrm{a}}$ & $95 \% \mathrm{Cl}$ & $\mathrm{OR}^{\mathrm{a}}$ & $95 \% \mathrm{Cl}$ & $\mathrm{OR}^{\mathrm{a}}$ & $95 \% \mathrm{Cl}$ \\
\hline \multicolumn{21}{|c|}{$\begin{array}{l}\text { Year preceding } \\
\text { birth }\end{array}$} \\
\hline Male pilots & 0.78 & $0.54-1.13$ & 0.88 & $0.72-1.08$ & 0.85 & $0.70-1.03$ & 30.85 & $0.65-1.11$ & 10.72 & $0.51-1.03$ & 3. & . & 0.67 & $0.17-2.69$ & 9 . & . & 0.36 & $0.05-2.52$ & 21.41 & $0.53-3.76$ \\
\hline Reference & 1 & . & 1 & • & 1 & . & 1 & . & 1 & . & . & . & 1 & . & - & . & 1 & . & 1 & . \\
\hline $\begin{array}{l}\text { Female } \\
\text { attendants }\end{array}$ & 1.02 & $0.76-1.38$ & 0.83 & $0.69-0.998$ & 80.95 & $0.81-1.12$ & 21.03 & $0.82-1.28$ & 30.96 & $0.73-1.26$ & 60.87 & $0.22-3.50$ & 01.13 & $0.42-3.02$ & 0.79 & $0.11-5.59$ & 90.87 & $0.28-2.70$ & 1.44 & $0.60-3.47$ \\
\hline Reference & 1 & $\cdot$ & 1 & · & 1 & . & 1 & . & 1 & · & 1 & $\cdot$ & 1 & $\cdot$ & 1 & . & 1 & · & 1 & $\cdot$ \\
\hline \multicolumn{21}{|l|}{ Ever } \\
\hline Male pilots & 0.85 & $0.61-1.18$ & 0.91 & $0.76-1.10$ & 0.76 & $0.76-1.08$ & 31.10 & $0.70-1.16$ & 0.91 & $0.54-1.05$ & 5. & . & 0.90 & $0.29-2.81$ & 1. & . & 0.32 & $0.04-2.26$ & 61.24 & $0.46-3.30$ \\
\hline Reference & 1 & $\cdot$ & 1 & $\cdot$ & 1 & • & 1 & $\cdot$ & 1 & $\cdot$ & 1 & . & 1 & $\cdot$ & 1 & . & 1 & . & 1 & • \\
\hline $\begin{array}{l}\text { Female } \\
\text { attendants }\end{array}$ & 0.96 & $0.74-1.25$ & 0.82 & $0.70-0.96$ & 0.93 & $0.81-1.08$ & 31.15 & $0.95-1.38$ & 31.11 & $0.88-1.39$ & 90.98 & $0.31-3.03$ & 30.85 & $0.32-2.27$ & 1.18 & $0.29-4.74$ & 41.36 & $0.61-3.04$ & 41.79 & $0.93-3.45$ \\
\hline Reference & 1 & $\cdot$ & 1 & $\cdot$ & 1 & . & 1 & . & 1 & $\cdot$ & 1 & $\cdot$ & 1 & $\cdot$ & 1 & $\cdot$ & 1 & . & 1 & $\cdot$ \\
\hline
\end{tabular}

a Odds ratios adjusted for maternal age, year of birth, and place of birth.

b Odds ratio adjusted for maternal age, birth order, year of birth, and place of birth.

Table 3. Perinatal mortality and the occurrence of low birthweight, preterm birth, and selected birth defects among the infants of 3693 female cabin attendants by the mother's number of licensed workdays during the year preceding birth and all the years prior to birth and among all other infants (reference) in Norway in 1967-1995.

\begin{tabular}{|c|c|c|c|c|c|c|c|c|c|c|c|c|c|c|c|c|c|c|c|}
\hline \multirow[t]{2}{*}{ Exposure } & \multirow[t]{2}{*}{$\begin{array}{l}\text { Infants } \\
(\mathrm{N})\end{array}$} & \multirow[t]{2}{*}{$\begin{array}{l}\text { Perinatal } \\
\text { mortality } \\
\text { (Per } 1000\end{array}$} & \multirow[t]{2}{*}{ N) } & \multirow{2}{*}{$\begin{array}{l}\text { Low } \\
\text { birthweight } \\
(\%<2.5)\end{array}$} & \multirow{2}{*}{$\begin{array}{l}\text { Preterm } \\
\text { birth } \\
(\%<37 \\
\text { weeks })\end{array}$} & \multicolumn{2}{|l|}{$\begin{array}{l}\text { Birth } \\
\text { defects }\end{array}$} & \multicolumn{2}{|c|}{$\begin{array}{l}\text { Major } \\
\text { birth defects }\end{array}$} & \multicolumn{2}{|c|}{ Neural tube } & \multicolumn{2}{|l|}{ Total cleft } & \multicolumn{2}{|c|}{ Cleft palate } & \multicolumn{2}{|c|}{ Hypospadias } & \multicolumn{2}{|l|}{$\begin{array}{l}\text { Down } \\
\text { syndrome }\end{array}$} \\
\hline & & & & & & Per 10000 & $\mathrm{~N}$ & Per 10000 & $\mathrm{~N}$ & Per 10000 & $\mathrm{~N}$ & Per 10000 & $\mathrm{~N}$ & Per 1000 & $\mathrm{~N}$ & Per 10000 & $N$ & Per 10000 & $\mathrm{~N}$ \\
\hline \multicolumn{20}{|l|}{$\begin{array}{l}\text { Year preceing } \\
\text { birth }\end{array}$} \\
\hline Total exposed & 2512 & 17.5 & . & 4.9 & 5.9 & 326.4 & . & 203.0 & . & 7.8 & . & 15.9 & . & 4.0 & . & 11.9 & . & 19.9 & . \\
\hline Reference & 1621186 & 17.9 & . & 5.1 & 6.3 & 277.2 & . & 183.5 & . & 9.5 & . & 14.0 & . & 5.0 & . & 12.7 & . & 10.3 & . \\
\hline \multicolumn{20}{|l|}{ Ever } \\
\hline \multicolumn{20}{|l|}{ Workdays } \\
\hline Above median & 1673 & 20.3 & 34 & 5.1 & 6.2 & 346.7 & 58 & 233.1 & 39 & 12.0 & 2 & 17.9 & 3 & 12.0 & 2 & 17.9 & 3 & 29.9 & 5 \\
\hline Below median & 1673 & 14.3 & 24 & 4.3 & 6.0 & 358.6 & 60 & 221.2 & 37 & 6.0 & 1 & 6.0 & 1 & - & . & 17.9 & 3 & 23.9 & 4 \\
\hline Total exposed & 3346 & 17.3 & . & 4.7 & 6.1 & 352.7 & . & 227.1 & . & 9.0 & . & 12.0 & . & 6.0 & . & 17.9 & . & 26.9 & . \\
\hline Reference & 1621186 & 17.9 & . & 5.1 & 6.3 & 277.2 & . & 183.5 & . & 9.5 & . & 14.0 & . & 5.0 & . & 12.7 & . & 10.3 & . \\
\hline
\end{tabular}

was more frequent, 18.9 per 10000 versus 10.3 (table 1), the adjusted odds ratio being 1.41 (table 2).

In general, the results observed for exposure the year preceding the year of birth were similar to those observed for exposure ever.

\section{Female cabin attendants}

For exposure the year preceding birth, perinatal mortality among the offspring of the cabin attendants was also lower than in the reference group (table 3). The adjusted odds ratios were close to unity (table 2 ). In addition, the proportion of low birthweight was lower, $4.9 \%$ versus $5.1 \%$ (table 3 ), and the adjusted odds ratio was 0.83 (95\% CI 0.69-0.998) (table 2). Birth defects, total and major and Down syndrome, were more frequent in the cabin attendant group.
For exposure ever, Down syndrome was more frequent in the cabin attendant group

Observations obtained in the special group of female cabin attendants according to hours in the air and dose of radiation (table 4) were similar to those obtained when analyzed according to the number of workdays (table 3).

\section{Discussion}

Concern has been expressed that occupational exposure in terms of aviation may cause adverse pregnancy outcomes. However, few studies have addressed the issue. Adverse outcomes among infants of male pilots have, as far as we know, never been studied. In our present 
Table 4. Perinatal mortality and the occurrence of low birthweight, preterm birth, and selected birth defects among the infants of the female cabin attendants by the mother's hours in the air and the calculated dose of exposure to cosmic radiation the year preceding birth and all years prior to birth and among all other infants (reference) in Norway in 1977-1998.

\begin{tabular}{|c|c|c|c|c|c|c|c|c|c|c|c|c|c|c|c|c|}
\hline \multirow[t]{2}{*}{ Exposure } & \multirow[t]{2}{*}{$\begin{array}{l}\text { Infants } \\
\text { (N) }\end{array}$} & \multirow{2}{*}{$\begin{array}{l}\text { Perinatal } \\
\text { mortality } \\
\text { (per 1000) }\end{array}$} & \multirow{2}{*}{$\begin{array}{l}\text { Low } \\
\text { birthweight } \\
(\%<2.5)\end{array}$} & \multirow{2}{*}{$\begin{array}{l}\text { Preterm } \\
\text { birth } \\
(\%<37 \text { weeks })\end{array}$} & \multicolumn{2}{|c|}{ Birth defects } & \multicolumn{2}{|c|}{$\begin{array}{l}\text { Major } \\
\text { birth defects }\end{array}$} & \multicolumn{2}{|l|}{ Total cleft } & \multicolumn{2}{|c|}{ Cleft palate } & \multicolumn{2}{|c|}{ Hypospadias } & \multicolumn{2}{|l|}{$\begin{array}{l}\text { Down } \\
\text { syndrome }\end{array}$} \\
\hline & & & & & Per 10000 & $\mathrm{~N}$ & Per 10000 & $\mathrm{~N}$ & Per 10000 & $\mathrm{~N}$ & Per 10000 & $\mathrm{~N}$ & Per 10000 & $\mathrm{~N}$ & Per 10000 & $\mathrm{~N}$ \\
\hline \multicolumn{17}{|l|}{$\begin{array}{l}\text { Year preceding } \\
\text { birth }\end{array}$} \\
\hline \multicolumn{17}{|l|}{ Hours in air } \\
\hline Above median & 495 & 22.2 & 6.1 & 6.6 & 404.0 & 20 & 262.6 & 13 & 40.4 & 2 & 60.0 & 3 & - & . & - & . \\
\hline Below median & 496 & 20.2 & 3.7 & 4.9 & 443.5 & 22 & 262.1 & 13 & - & . & - & . & 40.3 & 2 & 20.2 & 1 \\
\hline Total exposed & 991 & 21.2 & 4.9 & 5.8 & 423.8 & . & 262.4 & . & 20.2 & . & 30.3 & . & 20.2 & . & 10.1 & . \\
\hline Reference & 1124336 & 14.1 & 5.1 & 6.7 & 316.5 & . & 218.1 & . & 8.7 & . & 13.9 & . & 15.0 & . & 10.9 & . \\
\hline \multicolumn{17}{|l|}{ Dose } \\
\hline Above median & 496 & 30.3 & 6.1 & 6.4 & 404.0 & 20 & 242.4 & 12 & 20.2 & 1 & 60.0 & 3 & - & . & - & . \\
\hline Below median & 495 & 12.1 & 3.7 & 5.1 & 443.5 & 22 & 282.3 & 14 & 20.2 & 1 & - & . & 40.3 & 2 & 20.2 & 1 \\
\hline Total exposed & 991 & 21.2 & 4.9 & 5.8 & 423.8 & . & 262.4 & . & 20.2 & . & 30.3 & . & 20.2 & . & 10.1 & . \\
\hline Reference & 1124336 & 14.1 & 5.1 & 6.7 & 316.5 & . & 218.1 & . & 8.7 & . & 13.9 & . & 15.0 & . & 10.9 & . \\
\hline \multicolumn{17}{|l|}{ Ever } \\
\hline \multicolumn{17}{|l|}{ Hours in air } \\
\hline Above median & 546 & 25.6 & 5.2 & 6.5 & 366.3 & 20 & 256.4 & 14 & 18.3 & 1 & 18.3 & 1 & - & 2 & - & . \\
\hline Below median & 547 & 16.5 & 4.1 & 5.7 & 438.8 & 24 & 237.7 & 13 & 18.3 & 1 & 36.6 & 2 & 36.6 & 2 & - & . \\
\hline Total exposed & 1093 & 21.0 & 4.6 & 6.1 & 402.6 & . & 247.0 & . & 18.3 & . & 27.4 & . & 18.3 & . & 9.1 & . \\
\hline Reference & 1124336 & 14.1 & 5.1 & 6.7 & 316.5 & . & 218.1 & . & 8.7 & . & 13.9 & . & 15.0 & . & 10.9 & . \\
\hline \multicolumn{17}{|l|}{ Dose } \\
\hline Above median & 547 & 22.0 & 4.8 & 6.2 & 348.0 & 19 & 219.8 & 12 & 18.3 & 1 & 36.6 & 2 & - & . & 18.3 & 1 \\
\hline Below median & 546 & 20.1 & 4.4 & 6.1 & 457.0 & 25 & 274.2 & 15 & 18.3 & 1 & 18.3 & 1 & 36.6 & 2 & - & . \\
\hline Total exposed & 1093 & & 4.6 & 6.1 & 402.6 & . & 247.0 & . & 18.3 & . & 27.4 & . & 18.3 & . & 9.1 & . \\
\hline Reference & 1124336 & 14.1 & 5.1 & 6.7 & 316.5 & . & 218.1 & . & 8.7 & . & 13.9 & . & 15.0 & . & 10.9 & . \\
\hline
\end{tabular}

study, airline pilots and cabin attendants were not, in general, at an increased risk of adverse pregnancy outcome. However, due to the number of cases in the exposed group, the statistical power was low, especially for neural tube defects, clefts, and hypospadias.

Previous studies of aviation and adverse pregnancy outcomes have included small numbers of persons and have mainly dealt with spontaneous abortions among flight attendants. A group in the United States found that spontaneous abortion, as reported by women, was almost twice as frequent among women usually employed as cabin attendants (16). Later, the same group suggested that the increased risk may be due to methodological limitations, and it concluded, in a subsequent study, that cabin attendants who work a relatively higher number of flight hours during pregnancy were not at increased risk of spontaneous abortion (17). Self-reported data on spontaneous abortion at low gestational ages are often subject to bias and are difficult to interpret, particularly if obtained in studies with low participation rates. On the other hand, a register-based Finnish cohort study found a slightly elevated risk of spontaneous abortion (18).

Our study comprised pregnancies after 16 weeks of gestation with far from complete coverage of spontaneous abortion, and no increased perinatal mortality was observed in any of the categories analyzed.
Due to larger numbers, we were able to look into more rare outcomes like birth defects. Still, even in this relatively large cohort of airline pilots and flight attendants, the estimates were hampered by low statistical power.

The tendency of less frequent adverse outcomes among infants of airline pilots may, to the extent this tendency does not represent random variation, be due to confounding. Airline pilots belong to a higher socioeconomic group, with lower risks of adverse pregnancy outcome. Thus we have previously reported strong effects of father's educational level on perinatal mortality (7). Alternatively, one may speculate that low doses of cosmic radiation may eliminate genetically unfavorable sperm or may cause genetically favorable modifications in sperms. However, the increased risk of Down syndrome is not compatible with such mechanisms.

The reduced risk of low birthweight and preterm birth observed among births of cabin attendants may also be due to the confounding effects of socioeconomic factors or smoking. In a previous study we have observed an association of low birthweight (OR 1.39, 95\% CI 1.35-1.43) and preterm birth (OR 1.20, 95\% CI 1.191.23) with low educational level (7), a finding consistent with the results obtained in other countries (19). The slightly increased occurrence of Down syndrome was in agreement with our previous observation (7). One may argue that the expected rate of Down syndrome, 
due to an assumed confounding effect of socioeconomic factors, should be lower than in the reference group. However, in our previous study, we found no effect of educational level on the rate of Down syndrome (7), as reported also in a study in the United Kingdom (20). Still, the increased rate of Down syndrome observed among infants of airline pilots and cabin attendants may be due to residual confounding by age. Furthermore, the stable secular trend of Down syndrome in Belarus before and after the Chernobyl accident (21) does not support an association with ionizing radiation. In general, one may argue that similar findings in the group exposed the year preceding birth and any year prior to the year of birth support a mechanism of confounding, which is also compatible with the lack of any dose-response association. On the other hand, even if the data on flight attendants were more specific in our present study than in our previous study, the relative risk estimates even in our present study may be biased towards unity due to the inclusion of unexposed mothers. The relatively small cohorts of exposed personnel in our present study preclude further clarification of the issue, and our findings of an increased occurrence of Down syndrome should be addressed in future studies.

\section{References}

1. Nicholas JS, Copeland KA, Duce FE, Friedberg W, O'Brian K. Galactic cosmic radiation exposure of pregnant flight crewmembers. Aviat Space Environ Med 2000;71:647-8.

2. Geeze DS. Pregnancy and in flight cosmic radiation. Aviat Space Environ Med 1998;69:1061-4.

3. Nicholas JS, Butler GC, Lackland DT, Hood WC Jr, Hoel DG, Mohr LC Jr. Flight deck magnetic fields in commercial aircraft. Am J Ind Med 2000;38:548-54.

4. Boice JD Jr, Land CE, Preson DL. Ionizing radation. In: Schottenfeld D, Fraumeni JF Jr, editors. Cancer epidemiology and prevention. 2nd ed. New York (NY): Oxford University Press; 1996:319-54.

5. International Agency for Research on Cancer (IARC). Static and extremely low-frequency (ELF) electric and magnetic fields, part 1: non-ionizing radiation. Lyon: IARC; 2002. IARC monographs on the evaluation of carcinogenic risks to humans 2002, vol 80.

6. Bound JP, Francis BJ, Harvey PW. Downs syndrome- prevalence and ionizing-radiation in area of North-west England
1957-91. J Epidemiol Community Health 1995;49:164-70.

7. Irgens $\AA$, Krüger K, Skorve AH, Irgens LM. Yrke og reproduksjonsutfall. En populasjonsbasert registerstudie, Norge 1970-1993 [Occupation and reproductive outcome, a population based register study in Norway 1970-1993]. Bergen (Norway): Department of Occupational Medicine, Haukeland University Hospital; 1996.

8. Tveten U. Cosmic radiation and airline pilots: exposure patterns of Norwegian SAS-pilots 1960-1994 [revised version]. Kjeller (Norway): Institute for Energy Technology; 1999. Institute for Energy Technology IFE/KR/E-99/002.

9. Tveten U. Cosmic radiation and airline pilots: exposure patterns of Norwegian pilots flying aircraft not used by SAS. Kjeller (Norway): Institute for Energy Technology; 1997. Institute for Energy Technology IFE/KR/E-97/003.

10. Haldorsen T, Reitan JB, Tveten U. Cancer incidence among Norwegian airline pilots. Scand J Work Environ Health 2000; 26(2):106-11.

11. Haldorsen T, Reitan JB, Tveten U. Cancer incidence among Norwegian airline cabin attendants. Int J Epidemiol. 2001;30; 825-30.

12. Tveten U, Haldorsen T, Reitan J. Cosmic radiation and airline pilots: exposure pattern as a function of aircraft type. Radiat Prot Dosimetry 2000;87:157-65.

13. Irgens LM. The Medical Birth Registry of Norway. Epidemiological research and surveillance throughout 30 years. Acta Obstet Gynecol Scand 2000;79:535-9.

14. The Medical Birth registry of Norway. Births in Norway through 30 years. Bergen (Norway): Medical Birth registry of Norway; 1997.

15. SPSS Inc. SPSS regression models ${ }^{\mathrm{TM}}$ 9.0. Chicago (IL): SPSS Inc; 1999.

16. Daniell WE, Vaughan TL, Millies BA. Pregnancy outcomes among female flight attendants. Aviat Space Environ Med 1990;9:840-4.

17. Cone JE, Vaughan LM, Huete A, Samuels SJ. Reproductive health outcomes among female flight attendants. J Occup Environ Med 1998;40:210-6.

18. Aspholm R, Lindbohm ML, Paakkulainen H, Taskinen H, Nurminen T, Tiitinen A. Sponaneous abortions among Finnish flight attendants. J Occup Environ Med 1999;41:486-91.

19. Pattenden S, Dolk H, Vrijheid M. Inequalities in low birth weight: parental social class, area deprivation, and "lone mother" status. J Epidemiol Community Health 1999;53: 355-8.

20. Vrijheid M, Dolk H, Stone D, Abramsky L, Alberman E, Scott JE. Socioeconomic inequalities in risk of congenital anomaly. Arch Dis Child 2000;82:349-52.

21. Lazjuk GI, Nikolaev DL, Novikova IV. Changes in registred congenital anomalies in the Republic of Belarus after the Chernobyl accident. Stem Cells 1997;Suppl 2:255-60.

Received for publication: 4 June 2002 